\title{
SYEKH ABDULLAH RAQI: ORANG MINANGKABAU PENYEBAR ISLAM DI PALU PADA ABAD XVII
}

\section{SYEKH ABDULLAH RAQI: MINANGKABAU PEOPLE, SPREADERS OF ISLAM IN THE PALU IN THE XVII CENTURY}

\author{
Ismail Syawal \\ Pusat Penelitian Sejarah Universitas Tadulako \\ Kampus Bumi Tadulako Tondo, Jl. Soekarno Hatta Km. 9 \\ Kota Palu - Sulawesi Tengah \\ e-mail: maield.thoratea@gmail.com \\ DOI: $10.36424 / j p s b . v 5 i 2.131$ \\ Naskah Diterima:29 Agustus 2019 Naskah Direvisi: 11 Oktober 2019 \\ Naskah Disetujui: 12 Oktober 2019
}

\begin{abstract}
Abstrak
Studi ini merupakan kajian sejarah lokal Lembah Kaili Sulawesi Tengah yang menceritakan kedatangan ulama Minangkabau ke Sulawesi Tengah sekitar tahun 1650. Perahu yang ditumpanginya berlabuh di "Karampe" (bahasa Kaili: terdampar) yang terletak dimuara Teluk Palu Provinsi Sulawesi Tengah. Penelitian ini menggunakan metodologi sejarah melalui empat langkah pokok metode sejarah, yakni: (1) heuristik, (2) kritik sumber, (3) interpretasi, dan (4) historiografi. Hasil penelitian ini menunjukkan bahwa Abdullah Raqi adalah salah satu dari sekian banyak penyiar agama Islam dari Minangkabau, memiliki peran penting dalam perjalanan sejarah Lembah Palu. Keberadaan Abdullah Raqi sebagai penyiar Islam di Palu Sulawesi Tengah diperkuat oleh beberapa peninggalan sejarah sebagai bukti bahwa beliau penyebar Islam pertama. Islamisasi di Sulawesi Tengah terjadi dalam tiga tahapan utama sejak masuk dan berkembangnya, yakni mitologis, ideologis, dan ilmu pengetahuan.
\end{abstract}

Kata Kunci: Syekh Abdullah Raqi, Ulama Minangkabau, Islam, Sulawesi Tengah.

\begin{abstract}
This study is a study of the local history of the Central Sulawesi Kaili Valley which tells of the arrival of the Minangkabau scholars to Central Sulawesi around 1650. The boat he was traveling at anchored at "Karampe" (Kaili Language: stranded) which is located in the mouth of Palu Bay in Central Sulawesi Province. This research uses historical methodology through four main steps of historical method, namely: (1) heuristics, (2) source criticism, (3) interpretation, and (4) historiography. The results of this study indicate that Abdullah Raqi is one of the many Islamic broadcasters from Minangkabau, having an important role in the history of the Palu Valley. The existence of Abdullah Raqi as an Islamic broadcaster in Palu, Central Sulawesi is reinforced by some historical heritage as proof that he was the first propagator of Islam. Islamization in Central Sulawesi
\end{abstract}


took place in three main stages since its entry and development, namely mythological, ideological, and scientific.

Keywords: Syekh Abdullah Raqi, Minangkabau Scholars, Islam, Sulawesi Tengah.

\section{PENDAHULUAN}

Azyumardi Azra dalam bukunya "Islam Nusantara Jaringan Global dan Lokal" telah banyak menjelaskan tentang hubungan Ulama-ulama Timur Tengah dengan Ulama-ulama Nusantara yang telah mengenalkan dan mengembangkan agama Islam di seluruh pelosok Nusantara termasuk Sulawesi Tengah. Salah satu ulama di Sulawesi Tengah yang diperkenalkan dalam buku tersebut adalah Sayid Idrus Bin Salim Aljufri pendiri perguruan Islam Alkhairat di Palu Sulawesi Tengah. Menurut Azra (2002: 170), selama di Indonesia Sayid Idrus mengabdikan dirinya dalam bidang dakwah saja. Padahal ulama-ulama yang membawa dan mengembangkan agama Islam di Palu Sulawesi Tengah bukan hanya Sayid Idrus Al Jufri saja tetapi bervariasi sebagai bagian dari perkembangan ulama-ulama Islam nusantara.

Islam masuk ke Sulawesi Tengah melalui tiga tahapan utama, yakni tahapan mitologis, ideologis, dan tahapan ilmu pengetahuan. Agama Islam di Palu Sulawesi Tengah dibawa oleh seorang ulama yang bernama Abdullah Raqi atau Dato Karama sekitar tahun 1650 dengan mengenalkan agama Islam secara mitologis. Kemudian, agama Islam dikembangkan oleh orang-orang Sulawesi Selatan termasuk La Iboerahima Wartabone dari Gorontalo pada tahun 1842 dengan mengembangkan agama Islam secara ideologis. Selanjutnya, agama Islam dikembangkan oleh Said Idrus bin Salim Aljufri dengan memperkenalkan agama Islam sebagai Ilmu Pengetahuan pada Perguruan Alkhairat pada tahun 1930 di Palu (Haliadi, Omar, dan Agustino, 2013).

Periode Islam mitologis di Palu Sulawesi Tengah ditandai dengan ceritacerita mitos tentang Agama Islam. Mitos mempunyai sifat irrasional sedangkan mitos juga berguna dan bermanfaat sebagai suatu konsensus. Pemikirannya diarahkan pada pemikiran reseptif artinya menerima segala sesuatu sebagai 
kodrat. Manusia tidak mungkin dan tidak perlu mengubahnya. Ia harus menerima apa adanya (Suparlan Suhartono, 2004: 40).

Periode mistis Islam di Sulawesi Tengah dinyatakan dalam riwayat pada abad ke-XVII datanglah sekelompok rombongan ke Tanah Kaili tepatnya di "Karampe" (Bahasa Kaili berarti terdampar) yang terletak di muara teluk Palu. Kelompok tersebut berjumlah kurang lebih 50 orang yang dipimpin oleh Datuk Karama atau Abdullah Raqi yang diikuti oleh istrinya yang bernama Ince Jille, iparnya bernama Ince Saharibanong, dan anaknya yang bernama Ince Dingko. Mereka datang dengan alat-alat kebesarannya dari Minangkabau seperti Bendera kuning, panji orang-orangan, Puade, Jijiri, Bulo, Gong, dan Kakula (Kulintang). Juga diriwayatkan bahwa yang menerima Islam pertama bernama Pue Bongo selaku pemimpin di daerah Kabonena Palu. Ketika Dato Karama tiba di Palu di daerah Kaili (Palu) bernama Pue Bongo belum memeluk agama dan nantinya dengan bantuan dari Dato Karama ini ia langsung memeluk Islam dengan kerelaan hatinya. Waktu perahu Dato Karama memasuki Teluk Palu diiringi dengan bunyi-bunyian (kakula, gong, dan alat-alat kesenian tradisional di lembah Kaili).

Menurut kepercayaan lokal, Dato Karama adalah seorang yang keramat, sehingga pada waktu memasuki Teluk Palu, arus sedang derasderasnya sehingga perahunya terdampar di pantai, tetapi setelah perahunya terdampar, perahu tersebut, berubah menjadi tikar yang membentang dan layarnya merupakan suatu perkemahan. Pantai tempat terdamparnya perahu Dato Karama itu disebut Karampe artinya tempat perahu terdampar. Tempat tersebut sampai saat ini disebut kampung Karampe. Rombongan Dato Karama, termasuk keluarganya menetap di Palu dan terjadilah perkawinan dengan turunan raja-raja. Hal itulah yang mempercepat proses perkembangan Islam di lembah Palu dan Sulawesi Tengah pada umumnya.

Tantangan utama pada periode ini adalah kepercayaan lama berupa sistem kepercayaan animisme dan dinamisme. Kepercayaan yang menjadi penghalang utama agama Islam adalah kepercayaan Karampue Langi dan Karampue Ntana (kepercayaan penguasa langit dan penguasa tanah), kepercayaa Wentira 
(kepercayaan: Tarapotina, Topepa, Buntulovo, Tauta, Divo, Tampilangi, Diava), kepercayaan gaib dari manusia yang hilang seperti: Tauleru dan Talivarani. Penyakit yang diderita manusia yang berasal dari mahluk halus seperti Viata dan Rate. Kepercayaan tentang doti (doti pontiala / lembek kepala), doti jori (lumpuh), doti apu (kulit terkelupas), doti butiti (perut kembung) dan semacamnya (Mahid dkk., 2009: 19-52; Adriani dan Kruyt, 1912: 299-301).

Tulisan ini terfokus pada Syekh Abdullah Raqi (Dato Karama) sebagai tokoh pembawa Islam awal di Palu Sulawesi Tengah, sebagai proses awal perkenalan masyarakat Palu dengan agama Islam. Sebelum agama Islam datang ke Palu Sulawesi Tengah, masyarakat masih memiliki pemahaman keagamaan yang bersifat animisme dan dinamisme. Proses masuknya Islam di tengah-tengah masyarakat yang animistik dan dinamistitik mampu dimasuki oleh agama Islam tanpa kekerasan dan menggunakan jalan damai.

\section{METODE PENELITIAN}

Penelitian ini mengacu pada metodologi sejarah dengan mengikuti empat langkah pokok yakni heuristik, kritik, interpretasi, dan historiografi. Metode sejarah ialah petunjuk pelaksanaan dan petunjuk teknis tentang bahan, kritik, interpretasi, dan penyajian sejarah (Kuntowijoyo, 2003: xix). Sedangkan Nugroho Notosusanto menyatakan bahwa metode sejarah ialah sarana sejarawan untuk melaksanakan penelitian dan penulisan sejarah. (Notosusanto, 1978: 11). Keempat langkah ini menjadi acuan pokok untuk merekonstruksi dinamika kehidupan yang dilalui tokoh tersebut. Rekonstruksi terhadap keberadaan Abdullah Raqi sebagai penyebar Islam pertama di Sulawesi Tengah. Heuristik merupakan tahapan yang dilakukan untuk mencari sumber-sumber sejarah. Dalam tahapan Heuristik, seorang sejarawan melakukan proses untuk mencari dan menemukan sumbersumber sejarah (Kuntowijoyo, 2003: xix).

Metode pencarian sumber dalam penelitian ini dilakukan dengan menggunakan studi kepustakaan, dan studi lapangan yakni observasi dan wawancara. Observasi diperlukan untuk menjajakinya. Jadi, berfungsi sebagai eksplorasi. Dari hasil ini kita dapat memperoleh gambaran lebih jelas tentang 
masalahnya dan mungkin petunjuk-petunjuk tentang cara memecahkannya. Sedangkan wawancara merupakan komunikasi verbal atau percakapan yang bertujuan mencari informasi. Interviu dilakukan antar dua orang (interview individual) tetapi dapat juga sekaligus diinterviu dua orang atau lebih [interview simultan] (S. Nasution, 2002: 106-113).

Setelah menemukan sumber, sejarawan melakukan tahapan kritik yang terdiri atas kritik ekstern dan kritik intern. Kritik ekstern bertugas menjawab pertanyaan tentang kebutuhan, keaslian, dan keutuhan sumber sejarah, sedangkan kritik intern dilakukan untuk membuktikan kesaksian sumber dapat dipercaya dengan cara penilaian intrinsik dan komparasi kesaksian-kesaksian sumber (Notosusanto, 1978: 38-40). Tujuan dilakukannya kritik adalah menyusun data untuk menjadi (menegakkan) faktan kemudian dilanjutkan dengan interpretasi atau penafsiran. Dalam hal ini, sejarawan memberikan penafsiran tentang sebuah peristiwa berdasarkan sumber-sumber yang ada, sehingga tercipta sebuah rangkaian peristiwa yang tersusun seperti sebuah kisah sejarah.

Ada tiga istilah yang selalu melingkari proses interpretasi, yakni pengelompokan fakta-fakta dengan berbagai hubungannya, formulasi dan presentasi hasil tafsiran, dan penggabungan (Sjamsuddin, 2007: 155). Interpretasi pada dasarnya didukung oleh analisis. Ilmu sejarah menggunakan analisis aktor (pelaku), analisis kondisional, dan analisis kausalitas. Analisis ini semakin menukik apabila dipadukan dengan pendekatan teoritis yang digunakan dalam penelitian ini. Terakhir, sejarawan melakukan tahapan historiografi atau penulisan sejarah dari hasil interpretasi terhadap sebuah peristiwa. Setelah melalui empat tahapan tersebut, karya sejarah dapat dipertanggungjawabkan secara ilmiah.

\section{PEMBAHASAN}

\section{Kepercayaan di Palu Sulawesi Tengah Pra-Islam}

Sederhananya, kepercayaan masyarakat lokal di Sulawesi Tengah dapat dikelompokkan menjadi dua yaitu kepercayaan animisme dan dinamisme. Animisme atau pemujaan terhadap roh yang berhubungan dengan kehidupan manusia, artinya roh yang dipercayai dapat membantu atau memudahkan 
kepentingan manusia, bahkan roh itu dapat mengganggu dan mencelakai seseorang (Nadjamuddin, 2002: 13-16). Masyarakat daerah ini juga mempercayai bahwa setiap benda (di alam) memiliki kekuatan ghaib yang dipercaya dapat memberi kedamaian maupun ancaman, baik secara kolektif terhadap masyarakat dan juga individu. Penyebabnya adalah ketidaklepasan manusia dengan lingkungan alamnya, baik agraris maupun maritim. Kepercayaan terhadap kekuatan gaib tersebut mampu mengatur sikap dan tingkah lakunya untuk mencapai kebahagiaan hidup. Hal inilah yang menjadi rambu-rambu (hukum adat) agar kiranya keseimbangan lingkungan alam tetap terjaga dengan baik. Itulah yang disebut dinamisme (Chalid, dkk, 1983/1984: 16).

Masyarakat Kaili mengenal atau percaya dengan keberadaan Karampua Langi (penguasa langit; roh yang mengatur iklim, cuaca, bulan dan matahari, gerhana bulan dan matahari, serta benda-benda langit lainnya), dan Karampua Ntana (penguasa tanah (bumi); karena dipercaya dapat mengatur kehidupan di bumi, gempa, banjir, angin ribut, dan lain-lain). Masyarakat ini juga percaya pada sebuah kekuatan arwah yang dapat menyembuhkan berbagai macam penyakit. Kekuatan menyembuhkan ini terlihat dengan adanya sebuah upacara ritual, Balia (Syuaib dan Bannu, 1994: 6-7). Tujuan pokok Balia, yaitu penyembahan (persembahan), permohonan dan perlindungan kepada kekuatan gaib sebagai sumber pemberi rezeki, keselamatan, sekaligus malapetaka bagi manusia. Sehingga dikenal empat macam Balia, yaitu Balia nto manuru, Balia bone meloso, Balia bone biasa (Salaude Utomanuru), dan Balia tampilangi (Chalid, dkk, 1983/1984: 34-35). Oleh karena itu, dapat dikatakan bahwa Balia merupakan salah satu ritus purba yang belum mendapat sentuhan pemikiran monoteisme. Hingga kini, upacara ritual ini masih dilakukan oleh masyarakat Kaili dan masih diyakini keampuhannya dalam menyembuhkan penyakit yang diderita oleh seorang (pasien).

\section{Kondisi Sosial Budaya di Palu Abad ke-XVII}

Pertengahan abad XVI, masa pemerintahan Raja Tunipalangga (15461565), Kerajaan Gowa berhasil memperluas hegemoninya hingga ke kawasan 
Teluk Palu. Meskipun demikian, Gowa tidak menempatkan seorang pejabat kerajaan sebagai Wakil Raja Gowa untuk wilayah Teluk Palu. Tradisi lisan masyarakat Teluk Palu menyebutkan bahwa penguasa-penguasa di wilayah Teluk Palu diyakini memiliki hubungan darah dengan penguasa Bugis-Makassar. Demikian juga sistem pemerintahan kerajaan di Teluk Palu mengikuti corak pemerintahan Kerajaan Bugis-Makassar.

Meningkatnya volume perdagangan di Teluk Palu pada abad ke XVII tidak dapat dipisahkan dari kemajuan Makassar masa itu. Menurut Reid, sejak awal abad XVII, Kota Makassar menjadi titik komersial, sebagai basis semua pihak yang sedang mencari jalan untuk menghindari usaha VOC memonopoli perdagangan rempah-rempah di Maluku. Portugis yang sejak dekade awal abad ke XVII, sering mengunjungi Makassar dan kota ini dijadikan sebagai basis utama mereka di Asia Tenggara setelah kejatuhan Maluku di tahun 1641. Politik pintu terbuka yang dijalankan oleh penguasa Makassar mendorong wilayah ini menjadi salah satu dari enam kota terbesar di kawasan Asia Tenggara yang sama besarnya dengan banyak ibukota negara-negara Eropa. Pedagang dari berbagai penjuru dunia hadir di Makassar, seperti Cina, Belanda, Inggris, Jerman, Denmark, Prancis, Spanyol, India, dan lainnya (Sairin, 2012; Baca Reid, "Pluralisme dan Kemajuan Makassar Abad ke-17”, dalam Roger Tol, dkk., (ed), 2009: 96).

Makassar dengan pelabuhannya menjadi lokasi ideal pertukaran barang ekspor dan impor. Mulai dari pertukaran barang di daerah pantai setempat, melalui lalu lintas perdagangan antar pulau yang sibuk seperti Kalimantan, Jawa, Maluku, Nusa Tenggara, Sumatera, dan Filipina hingga ke jalur perdagangan jarak jauh yang menghubungkan Eropa, India, dan Cina. Seiring dengan perdagangan antara Makassar dengan Manila semakin intensif pada abad XVII, volume perdagangan di wilayah Teluk Palu juga semakin meningkat. Hal ini menyebabkan kawasan Teluk Palu terhubung dengan jalur perdagangan maritim dunia. Pelabuhan di wilayah Teluk Palu seperti pelabuhan Donggala menjadi daerah transit yang cukup penting di Selat Makassar (Sairin, 2012).

Hegemoni Gowa atas wilayah Kaili di kawasan Teluk Palu berakhir setelah adanya Perjanjian Bungaya ditandatangani oleh Sultan Hasanuddin, Sultan 
Gowa XVI dan Kolonel Speelman, wakil VOC pada hari Jum'at tanggal 18 November 1667. Pasal 17 Perjanjian Bungaya berbunyi: "Sultan harus melepaskan segala haknya atas pulau-pulau Sula dan pulau lainnya yang termasuk dalam kekuasaan Ternate, seperti: Selayar, Muna dan seluruh daerah di pesisir timur Sulawesi, yaitu mulai dari Sanana sampai Manado, Pulau-pulau Banggai, Gapi dan lain-lainnya yang terletak antara Mandar dan Manado seperti Lambagi, Kaidipan, Toli-toli, Buwol, Dampelas, Balaisang, Silensak, dan Kaili” (Patunru, 1983: 53).

Perjanjian Bungaya menyebabkan wilayah Teluk Palu oleh VOC diserahkan kepada Kesultanan Ternate. Namun, hak kesultanan Ternate itu tidak berlangsung lama. Dalam struktur pemerintahan tradisional kaili di Lembah Palu dapat dijumpai istilah-istilah jabatan pemerintahan yang mirip dengan jabatan pemerintahan di Ternate, seperti Jogugu di Kerajaan Sigi dan Kapita di Kerajaan Palu, walaupun fungsinya sedikit berbeda dengan yang ada di Ternate. Pasca penandatanganan Perjanjian Bongaya, terjadi gelombang migrasi besar-besaran orang Bugis ke wilayah Palu.

Ada banyak istilah yang digunakan untuk menyebut kawasan Lembah dan Teluk Palu pada masa lampau diantaranya: Caile, Kylie, Kajeli, Cajeli dan Palosbaai (Teluk Palu). Menurut Kruyt, Kaili merupakan nama sebuah kampung dekat Tawaeli, di sekitar Pantoloan. Navarette menyebutnya "Kerajaan Caile". Padtbrugge menggunakan sebutan Kaili untuk wilayah Teluk Palu, sedangkan sumber VOC abad 18 mendefenisikan Kaili sebagai "penduduk yang bermukim antara Palu dan Tolitoli” (Sairin, 2012; Henley, 2005: 232-233). Mengutip kesaksian seorang serdadu VOC yang berkunjung ke wilayah sekitar Teluk Palu pada bulan September 1681, Valentijn mencatat Teluk Palu disebut juga Teluk Cajeli (baca: Kaili). Ia juga membedakan antara daerah Cajeli dan Palu.

Dalam buku Valentijn disebutkan bahwa Daerah Kaili terdiri dari dua puluh tiga negeri, yakni: Cajeli, Lero, Laboang, Wanni, Baja, Roedana, Badi, Kaymolove, Rano, Taipa, Batotela, Dolo, Mambora, Bizemaroe, Walawantoe, Sidondo, Prigi, Sigi, Plolo, Tonde-Biro, Bolo-Auw, Pakkoeli, dan Lindoe. Dari 23 negeri tersebut, 5 di antaranya berada di daerah pegunungan. Sisanya berada di 
pesisir. Adapun wilayah Palu terdiri dari delapan negeri, yakni: Taboelanga, Tagari, Tendame, Boya, Tatanga, Bongi, Laswangi, dan Poeloe (Valentijn, 1856: 213-215). Setiap negeri dipimpin seorang pemimpin yang disebutnya sebagai raja (koning). Adapun nama penguasa-penguasa di wilayah Teluk Cajeli, yakni: Toembo memimpin Cajeli, Forelo memimpin Lero, Gingi memimpin Laboang (baca:Labuan), Tengelina memimpin Wanni (baca: Wani), Tingassie memimpin Baja, Tondoe memimpin Roedana, Boejouw memimpin Taipa, Vi-u memimpin Plolo, Sappa memimpin Bizemaroe (baca: biromaru), Soebi memimpin Walawantoe, Jami-i memimpin Sidondo, Makrelinda memimpin Kaymolove (baca: Kayumalue), Gia mempin Prigi (baca: Parigi), Tambagge memimpin Rano, Gola memimpin Dolo, Tamaroemba memimpin Batotela (baca: Vatutela), Toewija memimpin Mambora, Samoesoe memimpin Sigi, Tolla-Nambo memimpin Tonde-Biro), Mene memimpin Bolo-Auw, Pangolovoe memimpin Lindoe, dan Roetoe memimpin Pakkoeli. Adapun penguasa-penguasa di daerah Palu yang disebutkan oleh Valentijn yakni Tontolippe memimpin Taboelanga, Injoela memimpin Tagari, Temitoewa memimpin Tendame, Reboli memimpin Tatanga, Tiko memimpin Bongi, Iloboe memimpin Laswangi (baca Lasoani), Beba memimpin Boya, dan Parindi memimpin Poeloe. Valentijn menjuluki Lembah Palu sebagai “Tanah Susu dan Madu”. Ia menyatakan bahwa:

"Lahan di sekitar Palu, sampai ke pegunungan, menawarkan keindahan seperti di Belanda, karena permukaannya datar dan memiliki tanah lempung berwarna hitam. Lahan itu dikelilingi gunung-gunung menjulang tinggi dan ditanami ribuan pohon kelapa. Terciptalah pemandangan yang indah, menawan, padang rumput penuh dengan sapi gemuk, kerbau, kuda, domba, kambing serta berbagai binatang liar. Di atas semuanya, lahan tersebut menghasilkan banyak sekali padi dan beras karena sawahnya dibajak dengan kerbau. Sungguh tanah yang penuh berkah" (Valentijn, 1856: 214; Li, 2012: 135).

Saat itu, kawasan Teluk dan Lembah Palu masih terdiri dari kampungkampung yang masing-masing dipimpin oleh seorang penguasa atau kepala suku. Pada masa itu, masih sering terjadi perang antar kampung atau suku dan juga 
kebiasaan mengayau1. Perang antar kampung ini pada akhirnya menyebabkan beberapa kampung melakukan persekutuan bersama untuk menghadapi musuh. Dari sinilah cikal bakal munculnya kerajaan-kerajaan besar di kawasan Teluk Palu, seperti Banawa, Sigi, Palu dan Tawaeli.

Kondisi sosial penduduk di sekitar Teluk Palu dan Lembah Palu, dijelaskan oleh Tania Murray Li, bahwa hubungan antar kampung dibangun melalui perkawinan, mitos asal usul bersama, perdagangan, atau kerjasama sementara saat menghadapi musuh bersama. Pusat kekuasaan politik tidak memiliki kekuatan berarti. Bahkan apa yang mereka sebut sebagai kerajaan di lembah Palu sebenarnya tidak lebih dari sekedar kumpulan beberapa kampung yang mengangkat salah seorang dari bangsawan mereka sebagai pemimpin yang ditinggikan (Li, 2012: 119-122). Pada akhirnya, persekutuan antar kampung itu membentuk Kota Patanggota di Palu.

Palu pada abad XVII bukanlah tempat yang sunyi. Dalam catatan Argensola disebutkan bahwa pada abad itu terdapat daerah yang memiliki kekuatan militer sebanyak 10.000 soldados, yang dimiliki raja "Pulo dan Yacua" di Sulawesi. Hal itu sangat memungkinkan bahwa daerah dimaksud adalah Palu dan daerah tetangganya. Sedangkan dalam dokumen VOC tahun 1674 menyebutkan bahwa Kaili memiliki kekuatan sebanyak 7.000 weerbare manen, pria dewasa yang dapat berfungsi sebagai pasukan jika terjadi perang. Sedangkan dalam laporan Padtbrugge (Gubernur Maluku) yang mengutip laporan seorang serdadu VOC tahun 1681, yang juga sebagaimana dikutip oleh Valentijn menyampaikan bahwa jumlah penduduk di wilayah Teluk Cajeli telah mencapai 9.000 jiwa yang terdiri dari 3.000 jiwa laki-laki dewasa, sedangkan penduduk Palu mencapai 3.000 jiwa yang terdiri dari 1.000 jiwa laki-laki dewasa. Jadi jika dijumlahkan, jumlah penduduk di Kawasan Teluk Palu (di luar wilayah Donggala) tahun 1681 mencapai 12.000 jiwa (Henley, 2005: 232-233; Valentijn, 1856).

\footnotetext{
${ }^{1}$ Mengayau atau nangae adalah salah satu kegiatan masyarakat dalam upacara penguburan para raja-raja saman dahulu. Upacara ini biasanya dilakukan dalam keluarga raja atau bangsawan, khususnya yang menjabat di pemerintahan sebagai Magau (raja).
} 


\section{Kedatangan Dato Karama di Palu}

Islam telah masuk dan berkembang di kawasan Teluk Palu semenjak Abad ke XVII. Di Kerajaan Banawa, Raja (Magau) yang diyakini sebagai pemeluk agama Islam pertama adalah I Toraya, seorang raja perempuan. Raja ketiga Banawa yang berkuasa antara tahun 1650-1698 itu memeluk Islam semenjak tahun 1652. Sementara itu, Magau ${ }^{2}$ yang pertama kali menganut agama Islam di Tawaeli adalah Magau Daesalemba, Magau Tawaeli ketiga yang memerintah antara tahun 1605-1667 (Mohammad Noor Lembah, 1985). Selain itu ia juga dikenal dengan gelar Madika Baka Tolu, sebuah gelar yang menunjukan bahwa beliau seorang Madika yang telah melakukan khitan sebagai wujud kewajiban bagi setiap laki-laki yang telah memeluk agama Islam.

Dalam cerita rakyat masyarakat Tawaeli, orang yang dipercaya sebagai penyebar agama Islam yang pertama di Tawaeli adalah Daeng Makondang yang diberi gelar Bulangisi. Ia diberi gelar Bulangisi karena tidak mengikuti kebiasaan masyarakat Tawaeli mengunyah sirih. Ia berasal dari Sendana, Mandar dan diyakini pernah berguru pada Syekh Yusuf (1626-1699) di Makassar. Ia kemudian menyebarkan Islam di Tawaeli dan berhasil mengislamkan Magau Daesalemba. Selain itu, ia juga dianggap sebagai orang yang pertama kali mengajarkan huruf al-Qur'an dengan ejaan Bugis di Tanah Kaili (Lembah, 1985).

Orang yang pertama kali memperkenalkan Islam di Palu adalah Dato Karama, yang berasal dari Minangkabau. Dato Karama tiba di Palu pada tahun 1606 (Eija-Maija Kotilainen, 1992: 47). Namun yang pasti pada tahun 1681, telah dijumpai pemeluk Islam di wilayah Palu (Valentijn, 1856).

Dalam Abad ke tujuh belas Agama Islam mulai masuk di Tanah Kaili dibawa oleh Abdullah Raqie gelar Dato Karama. Berkat toleransi Beliau dengan penduduk terutama raja-raja dan para terkemuka sangatlah menarik simpati semua orang terhadap Beliau dan keluarganya. Yang mulai memasuki Agama Islam raja

\footnotetext{
${ }^{2}$ Konsep Magau merupakan sebuah gelar/jabatan. Istilah Magau berasal dari bahasa Kaili "Malala movia gau", artinya: Dapat melakukan apa saja yang ia kehendaki, sepanjang tidak melanggar adat. (lihat: Syamsuddin Hi. Chalid dan Abdul Ghani Hali, Tadulako dalam Persepsi dan Konsep Budaya Komunitas Kecil Suku Kaili dan Suku Kulawi di Kabupaten Donggala, Palu: Balai Penelitian Universitas Tadulako, 1981: 14-15).
} 
Kabonena I Pue Njidi Beliau pertama rela menanggalkan cawat dan mengganti kain sarung dipakai untuk sembahyang. Kemudian berangsur-angsur mendapat pengikut banyak, dan dibuatlah mesjid untuk mereka tempati sembahyang. Yang sangat menarik perhatian, di saat kedatangan beliau dengan ciri-ciri kesaktiannya. Perahu ditumpangi Belaiu dan rombongannya masuk di waktu malam dan menakjubkan. Dari jauh telah dibunyikan "Tabea" tanda memberi penghormatan dengan dentuman tembakan meriam tiga kali. Lalu disusul dengan bunyi gong tanda menang dan selamat dalam perjalanan. "Bunyi-bunyian hiburanpun di Palu berupa kulintang, yang disebut: Ni Enje Nu gamba-gamba nte goo nte kakulana" sampai perahu mendarat. Yang lebih mengagumkan lagi ketika perahu masuk dengan derasnya sampai terdampar jauh ke darat.

Setibanya di darat perahu pecah dan tiba-tiba terwujud menjadi sebuah tikar besar terbentang dan layarnya menjelma menjadi perkemahan. Tempat ini dihutani pohon mangga. Karena peristiwa terdamparnya perahu Dato Karama, dinamakanlah tempat itu "Karampe" dimana sekarang ditempati Rumah Sakit Undata Palu. Dan pohon-pohon mangga yang ada di tempat itupun hingga kini disebut orang "Taipa Karampei" dari tempat ini, Beliau dan rombongan pindah dan memilih tempat yang agak luas di sebelah barat sungai, namanya: "Ri Lalere" dan hingga sekarang disebut kampung Lere, Lalere adalah sejenis rumput jalar bertumbuh di pantai.

Kedatangan Beliau dengan keluarga dan rombongannya sebanyak lima puluh orang, karena perselisihan dikalangan keluarganya, sehingga meninggalkan negerinya. Beliau asal dari Minangkabau (Sumatera) hijrah ke Tanah Kaili untuk selamanya. Isteri beliau nama Ince Jille, sedangkan puteri Beliau nama Ince Dingko dan adiknya Ince Sahribanon semua ikut hijrah dengan Beliau. Ince Dongko mendapat jodoh dengan Putera Kaili dan adiknya Ince Sahribanon mendapat jodoh dengan Putera Sulawesi Selatan. Mereka masing-masing mempunyai turunan banyak. Olehnya segala alat adat kebesaran Dato Karama berupa bendera kuning, panji orang-orangan, puade, jijiri, bulo dan bunyi-bunyian semuanya dipersembahkan kepada raja, maksudnya untuk mempererat ikatan keluarga setelah mereka kawin mawin. Alat-alat itu sampai sekarang masih 
dipakai dalam upacara perkawinan atau kematian raja-raja. Beliau dan keluarganya wafat dan dimakamkan di kampung Lere, sehingga tempat itu disebut “Dayo Dato Karama” (Abdullah, 1975: 20-21).

Sementara itu, dalam cerita rakyat Kaili yang dimuat dalam karya Kruyt dan N. Adriani, De Baree Sprekende yang diterbitkan pada tahun 1912, disampaikan bahwa kedatangan Dato Karama di Palu terjadi pada masa pemerintahan Pue Nggari. Berikut terjemahan cerita rakyat tersebut:

Cerita tentang pengaruh Islam di Palu dan Parigi diceritakan dengan cara ini: semua tanah Bugis dan Makassar diislamkan oleh orang Melayu, yang datang dari Minangkabau yang dikenal dengan nama Dato Karama. Ketika tanah yang disebut tadi diislamkan. Datuk Karama datang ke Buol, dimana juga orang-orang menerima Islam. Pada waktu itu kampung Palu belum terletak di pantai, tetapi di daerah pedalaman dan penduduk aslinya masih orang Toraja. Ketika itu terjadi, bahwa pengolah garam ke pantai, ketika mereka sibuk mencari ikan, sesuatu melihat kedatangan orang asing, terbawa ombak. Ketika datang ke pantai menjadi jelas itu adalah seorang laki-laki dan satu orang anak yang diatas tempat salat (sejadah) di laut. Pengambil garam menceritakan hal tersebut pada kepala kampung Paloe, yang disebut Pue Nggari, yang dengan segera pergi berkuda ke pantai. Sementara itu, sang pendatang baru, tiada lain adalah Datu Karama, dengan anaknya bahwa ia setuju (siuman), bahwa ketika disana orang-orang datang anak kecil berkata: "Datoe haruskan aku memasakan kofi untukmu", dari itu semua orang tahu bahwa ia adalah seorang Datoe. Begitu terpisah itu juga, namun disamping itu tidak mengerti Poee Nggari pada ucapan Datoe Karama, karena itu bahasa Melayu. Namun Datoe Karama seketika mengerti Pue Nggari, karena ia mobaraka (memiliki kekuatan ajaib). Orang-orang berkata kemudian satu sama lain melalui tanda tertentu dan Poee Nggari sangat terkejut atas sembahyang (sebuah kewajiban dari praktik keagamaan, lima kali sehari) Datu Karama. Banyak dia mengerti, bahwa Datu Karama adalah orang luar biasa, maka ia tidak ingin ia mati. Pue Nggari memberikan makanan pada Datu Karama, namun ini membuatnya jelas bahwa dia tidak memakan beras dan hanya minum kopi. Ketua ingin membawa pulang orang suci ini ke kampung, namun ini diceritakanya, bahwa dia tidak ingin pergi jauh karena disana itu bau kotoran babi. Maka Pue Nggari mendirikan gubuk untuk Datoe Karama di Pantai. Juga diberikan pada orang suci itu seorang perempuan, namun ia menolak, berkata bahwa dia tidak memiliki penis dan navel. Ia memulai (menyatakan) bahwa ketua sejak saat itu yakin dan sekarang yakin akan hal tersbut bahwa Datoe Karama adalah mubaraka. 
Kepala Palu pergi ke pantai setiap mengunjugi orang suci dan setiap satu sama lain dapat saling memahami, Datu Karama berkata bahwa sembahyang dapat menghilangkan sakit dan nasi melakukan kesuksesan dan bahwa lakilaki harus boleh disunat. Namun Pue Nggari menginginkan dari sini tidak satupun yang tau. Ketika hal tersebut terjadi pada waktu tertentu, bahwa disana penyakit akibat babi terjadi yang membuat semua hewan ini mati. Sang ketua mengeluh pada sang suci, namun ia menjawab bahwa setiap hal itu adalah takdir dari tuhan (Ala ta'ala).

Pada waktu pertama kali Datu Karama tinggal di Palu, istri dari Pue Nggari sedang mengandung dan ketika ia melahirkan, suaminya mengirim orang dengan segera ke Datoe Karama untuk bertanya harus di beri nama apa anak tersebut. Sang suci tengah dalam keadaan solat ketika utusan datang. Ketika ia selesai berdoa, ia kemudian berkata pada mereka: "sapa orang". Utusan itu menganggap bahwa itu adalah nama bagi anak yang lahir itu , dan kembali pulang; namun ditengah jalan ia lupa orang Melayu dan mengusulkan sebelumnya di tempat Paloe taoe, sehingga ia memberitahukan pada sang kepala suku bahwa anak itu harus dinamai Sapataoe, kemudian menjadi La Pataoe, satu yang bagi orang Kaili masih menjadi nama yang umum dari anak kepala suku.

Atas Islam orang-orang Paloee ingin diantaranya tidak ada satupun yang mendengar. Ketika hal itu terjadi, bahwa La Patau sakit berat dan akhirnya perwakilan anak Pue Nggari pesan kepada Datu Karama, mengatakan: ketika ia anak saya membaik, Ia harus disunat". Sang suci mengambil air, meniup atasnya dan melapalkan doa atasnya. Air ini diperintahkan untuk diminum oleh anak itu. Ketika La Patau meminum air tersebut, ia menjadi sembuh dan mengikuti janji sang ayah ia disunat. La Patau merupakan orang Islam pertama di Palu. Setelah ayahnya meninggal, ia memindahkan kampungnya ke pantai pada tempat yang saat ini dikenal dengan Palu.

La Patau menikahi sepupunya, dan mendapatkan dari pernikahanya satu anak yang namanya nampaknya tidak lagi dikenal, setidaknya tidak ada orang mengetahuinya dan menyebut namanya. Ia menikahi sepupunya, namun tidak memiliki anak. Atas saran dari Datu Karama pergilah anak dari La Patau ke Minangkabau dan menikah seorang anak kepala suku disana yang darinya ia memiliki anak. Ia kemudian kembali ke Paloe ketika ia menyesal, karena seluruh keluarganya meninggal, dan dengan ijin semua ditentukan sementara menjadi dewasa anak perempuan dari La Pataoe kemudian dari minangkabau dikirim ke Paloe. Ini (cerai) berpisah dan ketika kapal laut ke Paloe datang, orang-orang membunyikan gong, yang sejak saat lalu diperkenalkan kepada orang Palu. Putri tersebut menikah 
dengan anak dari kepala suku Kaili dan darinya muncul pemimpin Palu saat ini. Kubur dari Datu Karama ditemukan di Palu dan dianggap sebagai tempat suci.

Bersama dengan anak perempuan yang kecil dari La Patau dari Minangkabau datanglah sepupu dari Datu Karama, yang terkenal dengan nama Datu Mangadji (tuan pembaca Qur'an). Mereka pergi ke Parigi untuk mengIslamkan orang Parigi, yang pada saat itu masih dalam keadaan pagan [belum beragama], (Kruyt dan Adriani, 1912: 299-301).

\section{Abdullah Raqi (Dato Karama): Penyebar Islam di Palu}

Perjalanan sejarah Islam di Sulawesi Tengah berbeda dengan daerahdaerah lain di Indonesia. Memang di daerah ini tidak terdapat sebuah kerajaan yang menjadi kerajaan Islam dan mampu mengembangkan kekuasaannya. Sehingga daerah ini dalam proses penyebaran Islam, kurang terkenal walaupun banyak terdapat peninggalan Islam yang diperkirakan lebih tua dari yang pernah ada di negeri ini. Namun, sejarah perkembangan Islam mencatat bahwa di Sulawesi Tengah terdapat kenyataan perkembangan Islam yang spesial, sebagai sebuah peran tersendiri dan berbeda dengan perkembangan Islam di daerah-daerah lain di Indonesia.

Perkembangan Islam yang berbeda disebabkan oleh adanya faktor geografis, dan keadaan alam yang bekerja dalam proses penyebaran Islam. Sehingga terjadi kelangkaan sumber atau kekurangan data sebagai bukti-bukti sejarah tertulis guna mendukung kebenaran suatu berita. Banyak anggapan masyarakat yang ditangkap dari sumber lisan bahwa Islam masuk ke Lembah Palu melalui tiga tahap, dan berasal dari tiga daerah yang telah menjadikan Islam sebagai agama masyarakat. Berita ini diperkuat dalam buku "Sejarah Sulawesi Tengah" yang mengatakan bahwa "Islam masuk Sulawesi Tengah melalui tahaptahap, yaitu: Pertama, dari Ternate yang masuk melalui Gorontalo dan tiba di Lambunu pantai Teluk Tomini; Kedua, dari Minagkabau yang dibawa oleh Abdullah Raqie dan dilanjutkan oleh orang-orang Bugis Mandar. Keberadaan orang-orang Bugis ini diperkuat oleh ejaan mengaji yang dipergunakan yaitu dengan mengeja menggunakan bahasa Bugis; dan Ketiga, Dilanjutkan orang Arab 
yang dibawa langsung dari Hadramaut oleh Sayid Idrus bin Salim Al Jufri (Nainggolan, dkk, 1996/1997).

Sofyan B. Kambay menyatakan bahwa Islam masuk ke Palu sekitar abad ke-XVII Masehi (1650) yang dibawa oleh seorang muballiq berasal dari Sumatera Barat (Minagkabau) bernama Abdullah Raqie atau lebih dikenal dengan nama Dato Karama (Kambay, 1991: 6). Pernyataan ini dipertegas dalam buku berjudul "Mengenal Tanah Kaili" yang menyatakan bahwa dalam abad XVII agama Islam mulai masuk ke tanah Kaili dibawa oleh Abdullah Raqie gelar Dato Karama (Abdullah, 1975:20).

Abdullah Raqi adalah ulama besar dari Minangkabau, ia lahir di Pesisir Selatan Sumatera Barat dan wafat di Lembah Palu. Pada usia 22 tahun, Abdullah Raqi dibawa ayahnya ke Mekkah untuk menimba ilmu pengetahuan. Abdullah Raqi adalah seorang ulama yang rendah hati, teguh dalam pendirian dan hatinya lembut, walaupun beliau menguasai banyak bidang ilmu. Ia berpegang teguh pada Mazhab Syafi dalam fiqih dan penganut Ahlussunnah wal Jamaah mengikuti ajaran Mazhab Imam Abu Hasan al-Asy’ari dan Imam Abu Mansur al-Maturidi dalam akidah. Abdullah Raqi adalah murid dari Syekh Abdurrauf Aceh (Ali, 2014: 47). Selain itu, Abdullah Raqi juga dikenal sebagai ulama yang sangat peduli terhadap pencerdasan umat. Beliau menguasai ilmu fiqih, sejarah, tarekat/tasawuf, ilmu hitung dan geometri. Abdullah Raqi dapat memprediksi dan menentukan arah kiblat, serta berfungsi untuk mengetahui rotasi bumi dan membuat kompas yang berguna saat berlayar.

Selama di tanah suci, Abdullah Raqi menempuh pelajaran intensif tentang ilmu tarekat serta memasuki suluk di Jabal Abu Qubaisy. Pendalaman intensif tersebut, Abdullah Raqi dikukuhkan sebagai ahli tarekat yang memperoleh ijazah dari Tarekat Naqsyabandiyah. Pada tahun 1637, Abdullah Raqi kembali ke Nusantara. Ia memilih mengamalkan ilmunya secara langsung kepada masyarakat dan mengajarkan ilmu tauhid dan ilmu al-Qur'an. Penyampaian dakwah Abdullah Raqi ditempuh secara privat tanpa menggunakan sistem kelembagaan dan organisasi pendidikan. Kiprah dakwahnyalah yang memberi warna baru di bidang kegiatan keagamaan di Sumatera Barat (Ali, 2014: 48). 
Pada tahun 1637, Abdullah Raqi diundang oleh Sultan Iskandar Muda Aceh untuk bermusyawarah tentang penyebaran dan perkembangan Islam di Pulau Sulawesi yang dihadiri utusan Sultan Babullah Ternate. Musyawarah itu telah disepakati Abdullah Raqi berdakwah di Pulau Sulawesi dan berkoordinasi dengan Kerajaan Ternate untuk melakukan pemetaan dakwah di wilayah tersebut. Waktu keberangkatan menyebarkan Islam di Pulau Sulawesi sepenuhnya diserahkan kepada Abdullah Raqi (Ali, 2014: 49).

Perjalanan panjang yang ditempuh Abdullah Raqi bersama rombongan dari Sumatra Barat menuju Lembah Palu Sulawesi Tengah pada tahun 1650, tentunya mengalami petualangan berat di Samudra Hindia dengan tantangan laut yang diterpa ombak dan tiupan angin. Kapal yang di tumpanginya tentu dengan kondisi yang cukup memadai, karena setelah berlabuh di Lembah Palu Sulawesi Tengah tidak ada lagi pelabuhan berikutnya yang dituju. Artinya, kapal itu terakhir dipakai oleh Abdullah Raqi dan rombongannya di Lembah Palu.

Kedatangan Dato Karama disambut baik oleh masyarakat Lembah Palu (Kota Palu) bahkan kedatangannya disambut oleh Raja Pue Njidi, Raja Palu yang pertama kali memeluk agama Islam. Beliau disebut Dato Karama karena memiliki kesaktian yang amat hebat (keramat dan sakti) dibuktikan pada saat ketika ombak tinggi setinggi pohon kelapa terjadi didaerah Palu dan ketika itu beliau melemparkan sorbannya hingga ombak tersebut berbalik arah ke desa Tambu.

Keberadaan Dato Karamah atau Abdullah Raqi telah membawa perubahan yang sangat besar dalam kehidupan masyarakat Palu, khusunya menyangkut kepercayaan yang dianut oleh masyarakat Sulawesi Tengah. Dimana, masyarakat bersedia memeluk agama Islam yang dibawa oleh Dato Karama. Peristiwa tersebut diyakini masyarakat Kaili sebagai kejadian keramat, sehingga Abdullah Raqi digelari "Dato Karama". Untuk mengenangnya, sebuah Sekolah Tinggi Agama Islam Negeri di Palu diberi nama (STAIN Dato Karama).

Ada beberapa peninggalan sejarah sebagai bukti bahwa beliau datang dan menyebarkan agama Islam di Lembah Palu, seperti Masjid Jami' (sekarang berada di kampung Baru), rumah adat (sudah terbakar), dan ciri makamnya berbentuk rumah gadang (minang), disesuaikan dengan daerah asalnya yaitu Minangkabau, 
Sumatera Barat. Olehnya itu, keberadaan Dato Karama sebagai penyiar Islam di Palu, Sulawesi Tengah pada umumnya diperkuat oleh beberapa peninggalan sejarah sebagai bukti bahwa beliau adalah penyebar agama Islam pertama di Lembah Palu pada abad ke XVII.

\section{Ajaran Dato Karama}

Dato Karama sebagai salah satu dari sekian banyak penyiar agama Islam dari Minangkabau. Abdullah Raqi dikenal sebagai ulama yang peduli terhadap pencerdasan umat. Dalam dakwanhnya, ajaran yang pertama kali disampaikan oleh Syekh Abdullah Raqi ketika mengajarkan agama Islam di Lembah Palu adalah cara berbusana karena pada saat itu masyarakat umumnya berpakaian dari kulit kayu. Ajaran ini ternyata mampu menarik simpati masyarakat sehingga mau masuk Islam. Setelah itu, barulah ia mengajarkan akhlak, mengaji, sholat, dan sebagainya. Dato Karama menjadi seorang guru pengaji di Kampung Baru, beliau pernah berjalan-jalan di sebuah kampung dan mendapatkan tumbuhan sejenis ilalang, ia kemudian menamakan kampung tersebut "Kampung Lere" yang awalnya merupakan jalan Panggona.

Sejak kedatangannya di Palu, Dato Karama menunjukkan ajaran Islam terkait hubungan antara manusia dengan alam (kosmologi). Properti alam yang dimanfaatkan Dato Karama antara lain, duduk di atas tombak dan berdiri di atas pohon lombok, bukanlah bermaksud sebagai unjuk kekuatan, namun sebagai bentuk korelasi kondisi sosial budaya di saat itu. Sebagaimana diketahui bahwa kondisi masyarakat Sulawesi pada abad XVI dan XVII, dalam euphoria pembentukan komunitas yang kemudian kerajaan-kerajaan kecil pimimpinan pertamanya disebut sebagai titisan sang pencipta atau titisan dewa. Seperti halnya di Kerajaan Bone, Luwu, Gowa, Tallo dan lain-lain, titisan itu disebut Tomanurung (manusia yang turun dari langit). Hal itu terjadi di Lembah Palu menganggap rajanya sebagai Tomanurung. Prosesi kosmologis tersebut tentunya sesuai dengan "bekal dakwah" Datu Karama. Oleh karena itu, duduk di atas tombak dan berdiri di atas tanaman pohon lombok, merupakan kesesuaian "ilmu" antara pendatang dengan pribumi. 
Ajaran kosmologis yang ditampilkan Datu Karama kepada masyarakat Lembah Palu, menjadi dasar untuk mengenal ajaran Islam setelah mengucapkan dua kalimat syahadat. Komunikasi kosmis antara manusia dengan alam pada kondisi masyarakat berkelabat dengan hutan rimba merupakan rangkaian teknologi, untuk memenuhi kebutuhan hidup sehari-hari. Pelatihan untuk mencapai derajat kosmik dalam ajaran Islam dikenal dengan riyadah. Kesuksesan pada riyadah lalu tercapailah tingkat ridha dengan tingkat dalam tirakat yang sudah ditempuh. Pada tingkat ini Allah memberi pencerahan kepada hambaNya. Manusia yang sudah mencapai tingkat ridha, sudah mampu mengenali dirinya dengan segala kemampuan dan kekuatan yang diberikanNya dalam menjalankan kehidupan sehari-hari.

Dato Karama dalam dakwahnya, menggunakan pendekatan syariat, budaya, seni dan tasawuf. Dalam pendekatan tersebut, Dato Karama menggunkan 5 pilar ajaran, antara lain: (1) Natau, artinya membuka cara pandang orang Kaili untuk memiliki ilmu pengetahuan. (2) Каsiromu Мри Каrja, artinya membentuk tim kerja dalam menyukseskan usaha bersama. (3) Namanusia Mpu, artinya mengimplementasikan prinsip-prinsip kemanusiaan dan interksi sosial, seperti: “Nemo Rakalingasi Tupu, Nemo Malanga Rara, Nemo Deraurusi, Nemo Masala Rapojarita, Nemo Madava, Nemo Rapovia Da". Atrtinya: "Jangan lupa Tuhan dalam segala aktivitas, jangan membanggakan diri, jangan mengabaikan lingkungan sekitar, jangan salah bicara, jangan berbohong, jangan menyinggung orang lain". (4) Mompakanoa Jarita, artinya jujur dalam berbicara. (5) Ponturo Pompeguru, artinya menjadikan diri sebagai pusat pembelajaran (Ali, 2014:73).

Setelah tahpan tersebut ajaran selanjutnya adalah Al-Mardiyyah yang mengajarkan ketenangan hidup bagaikan air mengalir dengan jernih, melalui bebatuan dengan menampilkan suara gemericik yang indah, melewati pepohonan besar dengan menampilkan suara gemuruh yang besenandung dengan dedaunan. Alam akan terasa gersang tanpa air, manusia tercipta dari setetes "air" sehinggan nusantara Indonesia disebut Tanah Air. 


\section{Makam Dato Karama: Halte Terakhir Sang Ulama}

Mengenai tahun wafatnya Abdullah Raqi tidak diketahui secara pasti. Tidak adanya bukti tertulis yang dapat menjadi acuan merupakan penyebab diskontinuitas sejarah. Setelah wafat, Abdullah Ragi dimakamkan di Kampung Lere, Kota Palu. Makam Abdullah Raqi ditetapkan sebagai salah satu situs cagar budaya di Kota Palu. Secara keseluruhan, kompleks makam seluas $\pm 1.700 \mathrm{~m}^{2}$, sedangkan luas bangunan makam Abdullah Raqi sekitar $\pm 104 \mathrm{~m}^{2}$ dengan bentuk rumah Minangkabau. Dalam kompleks ini terdapat beberapa makam lain, seperti makam istri, ipar serta puteranya. Selain itu, ada juga makam pengikut setianya yang terdiri dari 9 makam laki-laki, 11 makam wanita, dan 2 makam tanpa keterangan jelas di nisannya.

Pada hari-hari tertentu, kompleks Makam Abdullah Raqi ini ramai dikunjungi peziarah. Para peziarah tidak hanya berasal dari Kota Palu, tetapi juga berasal dari daerah-daerah lainnya, seperti Donggala, Kulawi, Parigi, dan lainlain. Tujuan pengunjung yang datang ke makam ini dengan maksud yang berbedabeda. Sebagian besar datang untuk melakukan ziarah, sedangkan yang lain datang dengan tujuan untuk melakukan penelitian sejarah, misalnya para arkeolog, mahasiswa, maupun para pelajar.

Kompleks Makam Abdullah Raqi terletak di Jalan Rono, Kelurahan Lere, Kecamatan Palu Barat, Kota Palu, Provinsi Sulawesi Tengah. Akses menuju kompleks Makam ini cukup mudah karena terletak di Kota Palu dengan jarak kurang lebih $3 \mathrm{~km}$ dari pusat kota. Pengunjung dapat menggunakan angkutan umum (angkot) menuju ke lokasi makam. Kompleks makam ini dahulu dikenal cukup sakral yang hanya orang tertentu saja bisa masuk ke area makam. Namun, sekarang tempat ini menjadi salah satu obyek wisata religi yang bebas untuk dikunjungi oleh siapa saja setelah Pemerintah Kota Palu memberikan izin beberapa tahun silam. Hal ini penting mengingat nilai edukasi dan historis yang bisa diperoleh pengunjung dari situs cagar budaya tersebut. Kondisi makam saat ini sepertinya kurang terawat. Semak belukar tumbuh tak beraturan di sekita lokasi makam, tidak ada fasilitas penerangan di malam hari serta keadaan bangunan makam yang mulai tidak terurus. Hal ini tentunya menjadi pekerjaan 
rumah bagi pemerintah daerah untuk segera merehabilitasi salah satu peninggalan sejarah di Kota Palu Provinsi Sulawesi Tengah.

\section{PENUTUP}

Perjalanan sejarah Islam di Sulawesi Tengah berbeda dengan daerahdaerah lain di Indonesia, meskipun di daerah ini tidak terdapat kerajaan Islam dan mampu mengembangkan kekuasaannya. Namun, sejarah mencatat bahwa di Sulawesi Tengah terdapat kenyataan perkembangan Islam yang spesial, sebuah peran tersendiri dan berbeda dengan perkembangan Islam di daerah-daerah lain di Indonesia.

Syekh Abdullah Raqi adalah seorang Ulama dari Minagkabau penyebar Islam di Lembah Palu Sulawesi Tengah. Abdullah Raqi disebut Dato Karama oleh penduduk lokal Kota Palu yang berarti seorang Dato (datuk) yang sakti atau keramat. Dato Karama datang ke Sulawesi Tengah menyebarkan agama Islam sekitar awal abad ke XVII dengan menggunakan perahu layar.

Keberadaan Syekh Abdullah Raqi memiliki peran penting di Sulawesi Tengah sebagai salah satu Provinsi di Indonesia yang dibangun pada tahun 1964 dan sekarang menjadi 13 Kabupaten dan Kota, antara lain: Kota Palu, Kabupaten Donggala, Tolitoli, Buol, Sigi, Parigi Moutong, Poso, Tojo Unauna, Morowali, Morowali Utara, Luwuk Banggai, Banggai Kepulauan, dan Banggai Laut. Secara antropologis structural, ada korelasi positif antara kedatangan rombongan Syekh Abdullah Raqi dari Minangkabau dengan lingkungan Teluk Palu dan tokoh-tokoh elit lokal seperti Puen Njidi dan Pue Bongo dari Kerajaan di Lembah Palu Sulawesi Tengah.

Ajaran yang dibawa oleh Syekh Abdullah Raqi ke Lembah Palu Sulawesi Tengah adalah ajaran ar-riyadhah, ar-ridha, dan al-mardiyyah. Ar-riyadhah adalah optimalisasi latihan-latihan fisik dan rohani untuk mencapai target spiritual (maqamat). Dari latihan demi latihan tercapailah beberapa tingkat maqamat, salah satunya adalah ridha. Ajaran ini berasal muasal dari "Hizb Al-Bahr" yang di dalamnya terdapat riyadhah-riyadhah. Sementara itu, Ar-Ridha adalah tingkatan dimana perjalanan riyadah yang rela menerima putusan Allah. Ajaran terakhir 
ialah Al-Mardiyyah merupakan ajaran ketenangan hidup bagaikan air yang mengalir dengan jernih, melalui bebatuan dengan menampilkan suara gemericik yang indah, melewati pepohonan besar dengan menampilkan suara gemuruh yang besenandung dengan dedaunan. Ketiga ajaran ini terimplementasikan di Kaili dengan "natau, kasiromu три karja," dan "namanusia mpu (bahasa Kaili yang berarti hidup bekerja keras dan manusia sempurnah). 


\section{DAFTAR PUSTAKA}

Abdullah, M. Djaruddin, 1975. Mengenal Tanah Kaili. Palu: Badan Pengembangan Pariwisata Dati I Sulawesi Tengah.

Ali, Mohammad, 2014. Datuk Karama dan Islamisasi Masyarakat Kaili di Lembah Palu, Cirebon: Perwira.

Amining B., Dahlia S., 1994. Adat Balia di Tanah Kaili Kabupaten Donggala (Suatu Tinjauan Sosial Religius), Laporan Penelitian: Balai Penelitian Unversitas Tadulako Palu.

Azra, Azyumardi, 2002. Islam Nusantara Jaringan Global dan Lokal, Bandung: Mizan.

Hali, Abdul Ghani, dan Hi. Chalid, Syamsuddin, 1981. Tadulako dalam Persepsi dan Konsep Budaya Komunitas Kecil Suku Kaili dan Suku Kulawi di Kabupaten Donggala, Palu: Balai Penelitian Universitas Tadulako.

Henley, David, 2005. Fertility, Food and Fever; Population, Economy and Environtment in North and Central Sulawesi, 1600-1930, Leiden: KITLV Press.

Haliadi, Rahilah Binti Omar, Leo Agustino, Abdullah Raqiy dan Anwar Datuk Madjo Basah Nan Kuning: Elit Melayu Penganjur Awal Islam dan Pimpinan di Sulawesi Tengah, Indonesia, disampaikan pada seminar antarabangsa di Universitas Brunei Darussalam Negara Brunei Darussalam tanggal 29-31 Maret 2013.

Hi. Chalid, Syamsuddin, dkk, 1983/1984. Upacara Tradisional dalam Kaitannya Dengan Peristiwa Alam Dan Kepercayaan Daerah Sulawesi Tengah, Lapen, Proyek Inventarisasi Dan Dokumentasi Kebudayaan Daerah Direktorat Sejarah Dan Nilai Tradisional Departeman Pendidikan Dan Kebudayaan.

Kambay, Sofyan B., 1991. Perguruan Islam Alkhairaat: Dari Masa Ke Masa, Palu: Pengurus Besar Yayasan Alkhairaat.

Kotilainen, Eija-Maija, 1992. When The Bones are Left; A Study of the Material Culture of Central Sulawesi, Helsinki: The Finnish Antropological Society.

Kuntowijoyo, 2003. Metodologi Sejarah, Yogyakarta: Tiara Wacana. 
Kruyt, A.C., Adriani, N., 1912. De Baree-Sprekende Toradjas van Midden Celebes, Batavia: Landsrukkerij.

Li, 2012. The Will To Improve: Perencanaan, Kekuasaan, dan Pembangunan di Indonesia, Tangerang: Marjin Kiri.

Nadjamuddin, Lukman, 2002. Dari Animisme Ke Monoteisme: Kristenisasi di Poso 1892-1942, Yogyakarta: YOI.

Nainggolan, Nurhayati, dkk., 1996/1997. Sejarah Daerah Sulawesi Tengah. Jakarta: Depdikbud.

Nasution, S., 2002. Metode Research (Penelitian Ilmiah). Cet. Kelima, Jakarta: Bumi Aksara.

Noor Lembah, Mohammad, 1985. "Silsilah Kita Santina" Naskah Stensilan, Tawaeli.

Notosusanto, Nugroho, 1978. Masalah Penelitian Sejarah Kontemporer: Suatu Pengalaman, Jakarta: Yayasan Idayu.

Reid, Anthony. "Pluralisme dan Kemajuan Makassar Abad ke-17", dalam Roger Tol, dkk., (ed), 2009. Kuasa dan Usaha di Masyarakat Sulawesi Selatan, Makassar: Inninawa dan KITLV.

Sairin, Mohammad, 2012. "Dunia Maritim Teluk Palu Masa Prakolonial", dalam Midden Celebes Vol. I No.1 tahun 2012.

Sjamsuddin, Helius, 2007. Metodologi Sejarah, Yogyakarta: Ombak.

Suhartono, Suparlan, 2004. Dasar-dasar Filsafat, Yogyakarta: Ar-Ruzz.

Tol, Roger, dkk., (ed), 2009. Kuasa dan Usaha di Masyarakat Sulawesi Selatan. Makassar: Inninawa dan KITLV.

Patunru, Daeng, 1983. Sejarah Gowa. (Cet. II), Ujung Pandang: YKSS.

Valentijn. 1856 [Edisi pertama, 1724]. Oud en Nieuw Oost-Indien Deel I. [Ed. S. Keyzer], s'Gravenhage: H. C Susan. 